\title{
The Analysis of Soekarno's Speech on Nation Foundation: Demystifying the Ideology of Pancasila Using Foucauldian Methods
}

\author{
Martina Mulyani, VinaNurviyani \\ STKIP Pasundan, Indonesia \\ Universitas Suryakancana, Indonesia \\ martinamulyani@yahoo.com, vinanurviyani@yahoo.com
}

\begin{abstract}
Pancasila, as a nation foundation of Indonesia, is well known throughout the country. In order to know Pancasila in detail, it is significant to identify the founder of Pancasila, Soekarno, the first president of Indonesia. This paper is aimed to demystify Soekarno's speech that marked the birth of the five basic principles, Pancasila. Considering that speech is a kind of discourse in general, Foucauldian method is employed to analyze it. The analysis covered the context, surface of text, rhetorical means, and the ideological statement lying in the speech. The result of analysis revealed that through Pancasila, Soekarno wanted to spread the main spirit of gotongrojong which can be viewed as spirit to work together with everyone no matter who to gain justice, equality, and fairness. Soekarno believed that justice, equality, and fairness can be attained through the principles of socio- nationalism, socio democracy, and belief in God. If the socio- nationalism, socio democracy, and belief in God can work well so the unity for better Indonesia can be achieved.
\end{abstract}

Keywords: Soekarno's speech, Pancasila, Ideology, Gotong Royong

\section{INTRODUCTION}

Being independence is a dream of every person in the world. By becoming independent, a person can learn to support himself/herself and it is fundamental for any success one hopes to achieve. The same thing works for a nation. Every nation in the world wants to be independent and be able to decide its own way to achieve success. One of the successes of Indonesia as the independent country is creating the basic principles of Indonesia. In this case, Indonesia owns a foundation of nation which is well-known as Pancasila. It is the name offered by Soekarno as Indonesia's first President. The Indonesians acquaint with the elements of Pancasila as the basic principles one by one. Due to they have identified Pancasila since they are in the elementary school level even in some contexts in kindergarten level. However, not all the Indonesians know well the meaning behind Pancasila in real contexts. Therefore, the study of analyzing the ideology of
Pancasila referred by Soekarno as the founder of Pancasila is significant. By demystifying the ideology of Pancasila, it is expected that the readers are able to know Pancasila in depth and apply it in their daily life.

\section{METHODS}

President speech is a political discourse. Van Dijk (1997) refers political discourse as the text and talk of professional politicians or political institutions. Regarding, the text or the talk, Van Dijk classifies the political texts into several categories and Soekarno's speech on Pancasila can be included into political ideology. The next section discusses the ouline of Soekarnos's speech.

\subsection{Outline of the Speech}

Based on the content, the speech can be divided into:

1. Opening and stating the purpose of the speech (paragraph 1-2)

2. Identifying the meaning of independence (paragraph 3-13)

3. Proposing the foundation of the nation

a. Background of the proposal ( paragraph 14 -19)

b. Pointing out the first principle (paragraph 20- 25)

c. Pointing out the second principle (paragraph 26

d. Pointing out the third principle (paragraph 27 -29)

e. Pointing out the fourth principle (paragraph 30 -33)

f. Pointing out the fifth principle (paragraph 34 - 36)

4. Providing alternative (paragraph $37-42$ )

5. Closing (paragraph 43) 


\subsection{Political Ideology}

Political ideology is one type of political texts that shares basic belief systems that underlie and organize the shared social representations of groups and their members (see Van Dijk, 1997). Since Pancasila is considered as ideology, Pancasila can be seen as a system that consists of a set of basic social representations, which according to Van Dijk (1997), involves relevant values and sustains specific altitudes about properties (like power, equality, etc.) that characterize the system.

With refer to the above definition, Soekarno's speech on the birth of Pancasila can be seen as a political talk about preparing the system that shares social representation of Indonesia People. As political talk can be included into discourse in general, the current study applies the Foucauldian methods to analyze Soekarno's Speech. The following is the discussion the Foucauldian concept of critical discourse analysis.

\subsection{Foucauldian Concept of Critical Discourse Analysis}

Foucauldian defines discourse as power of exercise. The concept of power itself refers to a whole series of particular mechanism, definable and defined, that seem capable of inducing behaviors or discourse (Foucault, 1996, as cited in Wodak \& Meyer, 2009, p. 35). Viewing the definition, Foucauldian focuses its analysis on the discourse instead of the subject. Nevertheless, Foucauldian method tries to relate the discourse with the subject by analyzing the constitution of the subject in its historical and social context from diachronic (i.e. longitudinal) and synchronic (i.e. Cross-sectional) perspective (Foucault, 1996, as cited in Wodak \& Meyer, 2009, p. 38). Moreover, the following section provides some ideas on how discourse or the power of discourse can be analyzed systematically.

\subsection{The Analysis of Discourse}

The Soekarno's speech was analyzed by using the theory of discourse analysis proposed by Jager \& Maier (2001, p. 55) which cover the following aspects:

1. Context

With respect to context, the study tries answer the following questions.

- Who is the author? What is his position?

- What was the occasion for the article?

2. Surface of the text

The study tries to investigate the surface of the text by figuring out the answer to the questions

- How do the topics relate to each other and overlap (entanglements of discourse strands)?

3. Rhetorical means

To portray how Soekarno applied his power into discourse, the study attempts to answer the question below by utilizing the theory of psychology of persuasion from Kevin Hogan (2004)
- What argument strategy is used?

\section{RESULTS AND DISCUSSION}

The analysis of the Soekarno's speech attempts to link the discourse with the social process to decipher covert ideology and power of the discourse.

\subsection{Analysis of Context}

Soekarno delivered his speech in a meeting in front of the chairman (Paduka Tuan Ketua) and the member of Dokuritsu Zyunbi Tyoosakai, a Japanese term of BPUPKI (Badan Penyelidik Usaha Persiapan Kemerdekaan Indonesia). Soekarno started the speech by saying "Paduka Tuan Ketua yang mulia" as the opening lines. He may do this because BPUPKI was a committee created by Japanese who managed the independence for Indonesia. At that time BPUPKI was led by Dr. K.R.T. Radjiman Wedyodiningrat and the vice leader was Ichibangase who also acted as the chairman for the meeting (see Sejarah Negara, 2014).

Soekarno was asked to convey his idea on the foundation of the nation. The previous speeches concerning the Nation Foundation were delivered by Moh. Yamin and Prof. Soepomo. Soekarno, at that time, seemed to be able to convince the audience with his idea.

\subsection{Analysis Surface of the Text}

The day when Soekarno delivered his speech on Nation Foundation was declared to be the birth Pancasila. There are some discourse strands containing comment or opinion towards the declaration of the day. Some people considered power behind the allegation of the birthday of Pancasila (Susetiawati, 2011) and some others assumed that different from Moh. Yamin and Prof. Soepomo, Soekarno conveyed his original idea (Dynash, 2013). Although, the fact is the present five principles in Pancasila is different from the one offered by Soekarno, but Soekarno is the one who offered the name "Pancasila" (Wibisono, G. 2015).

\subsection{Analysis of Rhetorical Means}

This study employed the theory of psychology of persuasion proposed by Hogan (2004) to identify Soekarno's strategy to influence audience by associating the utterance used by Soekarno with the type of strategy in persuasion technique.

Soekarno began his speech by discussing the meaning of independence (paragraph 3-13). According to him, being independent was being politically independent. To help the audience comprehend the meaning of independence, Soekarno associated independence with bridge and tried to relate the function of bridge into the independence of Saudi Arabia and Sovyet Rusia. Through that strategy, Soekarno tried to persuade audience about the importance of being independent. It can be found in the speech, particularly in paragraph six and seven. Regarding to the paragraphs, it can be portrayed that Soekarno employed persuasive rhetorical 
strategy. He persuaded the audience with the use of rhetorical question.

In addition, Soekarno also made use power words, such as the use of words 'kita' (we), proper use of name such as 'Ibn Saud', 'Sun Yat Sen', 'Prof. Sorpomo', ' Moh. Yamin', etc., and the use of 'because'. The utterances can be found in the speech precisely in paragraph thirty one and thirty three.

Moreover, Soekarno also applied time pressure technique. It can be found in paragraph seven. Soekarno also utilized credibility technique to convince the audience. One strategy of credibility techniques is never to tell others more than they believe. It can be figured out in paragraph ten.

In addition, Soekarno used future pacing strategy. It can be found in paragraph nine and twenty-four. Besides, Soekarno applied hypnotic language pattern, such as the use of 'don't', and 'tell you'. The utterances can be seen in parahraph seven, twenty, and thirty-nine.

Referring to the explanation, it is clear here, that Soekarno's speech has power because Soekarno applied all principles of persuasive strategies.

\subsection{Analysis of Content and Ideological Statement}

In the study, the speech examined the foundation of a nation. The analysis discusses straight to the principles proposed by Soekarno. Soekarno in his speech offered five different principles: the Indonesian nationality, internationalism and humanity, socio-democracy, social welfare, and belief in one supreme God.

\subsubsection{Kebangsaan Indonesia/the Indonesian Nationality}

Soekarno proposed nationalism as first principle. He further explained that Indonesia had ever experienced national estate during Sriwijaya and Majapahit empires. Apart from that Indonesia is never a national estate. Based on this concept, national estate, according to Budiman (2013), may presuppose national state that is beyond the form of independent nation that once existed and is at the same time, merged from these nations into one nation state.

At present, the concept of nation estate rises the interpretation of NKRI consisted of some regional governments (Kementrian Sekretatiat Negara, 2010).

\subsubsection{Internationalism and Humanity}

Soekarno proposed internationalism and humanity as the second principle. Internationalism according to him is closely related to nationalism. Soekarno referred internationalism and nationalism as socio-nationalism.

Socio-nationalism is a combination of socialism and nationalism. According to Gellner (1983), nationalism is a political sentiment which holds that political and national should be congruent. In this respect, national is similar with state. The meaning of nationalism keeps on evolving. In 1990s the meaning of state refers to people who live in particular territory. Following this idea, socio-nationalism may mean that state has a duty to secure the welfare of its people (Dinghey, 2008, p. 49).

The meaning of socio-nationalism goes along with the meaning of internationalism proposed by Unger (2012). $\mathrm{He}$ asserts that internationalism is a policy whose core is constructive global citizenship. According to Unger, Constructive internationalism sees people all living on one planet, with the primary international interest making that planet safer. Constructive internationalism would place far greater emphasis on peaceful international cooperation, sustainable and equitable development and conventional as well as nuclear arms control (Unger, 2012).

\subsubsection{Mufakat/Socio-Democracy}

The third basic principle is democracy. Soekarno employed the word 'mufakat' (socio-democracy) to show that in case there is problem, it can be discussed through 'musyawarah' (deliberation). Through the word 'mufakat', He opened equal opportunities for every party from any religion to convince one to another the truth from their beliefs. He challenged every party to fight for the belief they hold.

The meaning of mufakat and musyawarah can be found in the third and the fourth definition of mufakat (see KBBI, 2016). It seems Soekarno assumed that the word mufakat and musyawarah are interchangeable. Musyawarah is originally from Arabic while mufakat comes from Caniago tribe, one of tribe in Minang who is so democratic and famous for its philosophy. This principle reveals the ideology of Soekarno. $\mathrm{He}$ believed inequality, and struggle for democracy. This ideology is supported by his belief, Islam that convinces the power of democracy (see Click, 2015)

\subsubsection{Kesejahteraan Sosial/Social Welfare}

The fourth principle is social welfare. Soekarno proposed economic system which is different from that of America's. It is economic democracy which is different from capitalist.

Moreover, Dolack (2012) views economic democracy as equal system of economy. Economic democracy means that everybody who contributes to production earns a share of the proceeds - in wages and whatever other forms are appropriate - and everybody is entitled to have a say in what is produced, how it is produced and how it is distributed, and that these collective are made in the context of the broader community and in quantities sufficient to meet needs, and that pricing and other decisions are not made outside the community or without input from suppliers, distributors and buyers.

Again, the fourth principle clearly emphasizes on equality, fairness and justice. 


\subsubsection{Ketuhanan yang Maha Esa/Believe in one Supreme God}

Soekarno believed that a state should give equal opportunity to its citizens to practice their own belief. He emphasized that Indonesians believe in God.

...in our country all religions have space to live.

Based on the principle, it can be seen that Soekarno believed in religious harmony to create the peace in the country.

The five principles offered by Soekarno can be compressed into three principles: socio-nationalism, sociodemocracy and belief in God. Moreover, according to Soekarno, the three principles can be narrowed down into one principle. It is Gotong Royong (work together). Based on Soekarno's point of view, it can be concluded that Gotong royong is a concept or spirit that allows the diversity to unity. Soekarno realized that Indonesia comprises different races, tribes, beliefs, and religions. Thus, it is the responsibility of the nation to create a situation or atmosphere that makes those in diversity to work together in harmony based on equality, justice, fairness, democracy (mufakat) and fight for better Indonesia.

\section{CONCLUSION}

Soekarno, through his five basic principles wanted to spread the main spirit of Pancasila. It is gotong royong which can be viewed as spirit to work together, with everyone no matter who he/she is, to gain justice, equality, and fairness. Soekarno firmly said that justice, equality, and fairness can be realized through grant socio-nationalism, socio democracy, and belief in God. Soekarno believed that through the principles of socio-nationalism, socio democracy, and belief in God the unity for better Indonesia can be achieved.

\section{REFERENCES}

Budiman, H. (2013). Renegotiating unity and diversity. In Nations, National Narratives and Communities in the Asia-Pacific (p. 232). N. Vasu, Y. Chin, \& K. Law (Eds.). New york: Routledge.

Click, R. Pail.(2015). Ayat-ayat tentang musyawarah (Budaya demokrasi). Retrieved from http://www.rpail.click/2015/09/ayat-ayat-dan-hadistentang-musyawarah.html.

Dinghey, J. (2008). Nationalism, social theory and durkheim. New York: Palgrave, Mac Milan.

Dolack, P. (2012). There is no democracy without economic democracy. Retrieved June 6, 2016, from https://systemicdisorder.wordpress.com/2012/09/05/the re-is-no-democracy-without-economic-democracy/

Dynash, J. (2013). Pancasila, pengertian, sejarah. Retrieved June 6, 2016, from http://sistempemerintahan- indonesia.blogspot.co.id/2013/07/pancasila-sejarahdasar-negara-pengertian-makna-lambang-nilaiideologi.html

Gellner, Ernest. (1983). Nations and nationalism. Blackwell: Oxford.

Hogan, K. (2004). The Psychology of persuasion: How to persuade others to your way of thinking (Sixth Ed.). Pelican Publishing Company Inc. Retrieved from http://sirpabs.ilahas.com/ebooks/Social

Interactions/The Psychology Of Persuasion How To Persuade Others To Your Way Of Thinking - Kevin Hogan.pdf.

Jager, S., \& Maier, F. (2001).Theoretical and methodological aspect of Foucauldian critical discourse analysis and dispositive analysis. In Methods of Critical Discourse Analysis (First, p. 204). R. Wodak\& M. Meyer (Eds.). California: SAGE Publications Asia- Pasific Pte. Ltd.

KBBI (Kamus Besar Bahasa Indonesia). (2016). http://kbbi.web.id/mufakat.

Kementrian Sekretatiat Negara RI. (2010). Pemerintah daerah. Retrieved June 6, 2016, from http://www.indonesia.go.id/en/regional-government

Sejarah Negara. (2014). Pembentukan BPUPKI 1 Maret 1945. Retrieved June 6, 2016, from http://www.sejarah-negara.com/pembentukan-bpupki1-Juni-1945/

Susetiawati, E. S. (2011, June 1). Tanggal 1 Juni, Sungguhkah hari lahir Pancasila? Kompasiana. Retrieved from http://www.kompasiana.com/srie/tanggal-1-junisungguhkah-hari-lahirpancasila_5500d72f813311491afa8006

Unger, C. D. (2012). A better internationalis. World Policy Journal. Retrieved from http://www.worldpolicy.org/journal/spring2012/betterinternationalism

Van Dijk, T. A. (1997). What is political discourse analysis? Political Linguistics, 11(vi), 11-52. Retrieved from http://discourses.org/OldArticles/What is Political Discourse Analysis.pdf

Wibisono, G. (2015, June 1). Menengok sejarah lahirnya Pancasila. Okezone. Retrieved from http://news.okezone.com/read/2015/06/01/337/115820 0/menengok-sejarah-lahirnya-pancasila

Wodak, R., \& Meyer, M. (2009). Methods of critical discourse analysis. London: SAGE Publication, Ltd. 
